\title{
An Evaluation of the Effect of Work Stress and Work Conflict on Employee Performance: An Evidence from Indonesia
}

\author{
Tri Suyantiningsih ${ }^{1 *} \quad$ Herlam Pradoto $^{2} \quad$ Anggara Ardya $^{3}$ \\ 1.STIE YPN Graduate School of Economics, Jl. Surotokunto 2 B6-7, Rawagabus, Karawang, West Java, \\ Indonesia. \\ 2.Ph.D. in Management, Universitas Muhammadiyah Yogyakarta \\ Jl. Brawijaya, Tamantirto, Kasihan, bantul Yogyakarta 55183, Indonesia. \\ 3.Master of Management, Universitas Tridinanti Palembang \\ Jl. Kapt. Marzuki 2446, Palembang 30129, Indonesia.
}

\begin{abstract}
This study aims to examine the influence, work stress, and work conflict on employee performance. This type of research is quantitative research. The study was at Palcomtech Vocational Training Center Palembang. The number of respondents was 30 people. The questionnaires distributed to employees in the form of measurements of work stress and work conflict and the distribution of the questionnaires to the head of division in the form of employee performance measurements. Data processing and analysis techniques use validity test, reliability test, classic assumption test, descriptive analysis, multiple linear regression, and coefficient of determination analysis. The results show that work stress and work conflict simultaneously and negatively affect employee performance. Partially, work stress and work conflict negatively affect employee performance.
\end{abstract}

Keywords: Job Stress, Work Conflict, Employee Performance.

DOI: $10.7176 / \mathrm{IKM} / 10-3-04$

Publication date: April $30^{\text {th }} 2020$

\section{Introduction}

Every organization needs human resources to mobilize and synergize other resources to achieve an organization's goals. The demands of organizations to obtain, develop, and maintain quality human resources are increasingly pressing following the dynamics of an ever-changing environment. Employees, together with their superiors, can set work goals and performance standards. The improvement of employee performance on an individual basis will encourage overall human resource performance, which s reflected in increasing productivity in terms of work

Companies that have effective and efficient human resources will make the company progress and develop rapidly. Everyone has their burden in completing work, both internal and external problems. A small example that occurs within the company is the pressure by superiors on subordinates that makes employees feel disturbed. A lot of work and heavy work from superiors can cause work stress, especially if the work has not been completed long, but coupled with a new job. Human resource management in the company must be managed as well as possible in order to prevent conflicts and excessive work stress so that employees can work by the tasks and responsibilities that have been given on time to achieve organizational goals.

Generally, the performance of employees in a company does not always increase; sometimes, employee performance decreases. Several factors can cause employee performance to decline, including work stress and work conflicts that occur within the company and must be faced by these employees. In modern life which is increasingly complex, humans will tend to experience stress if they are less able to adapt their desires to the reality that exists, both the reality that exists inside and outside themselves stress at work is a depressing condition that arises from human interaction with work (Evalina, 2016).

Employee performance dramatically affects the company's profit. Employees who perform well will always be maintained. Stated: "Performance is the work of the quality and quantity achieved by an employee in carrying out their duties" (Machado and Davim, 2018). companies always want profit, savings, and efficiency to maintain their companies, but in achieving these companies must be able to optimize employee performance

According to Dessler (2013), work stress is a complex, varied, and dynamic process in which the stressor, views about stress itself, brief responses, health impacts, and variables are interrelated. Job stress can be a source or work stressor that causes an individual reaction in the form of physiology, psychological, and behavior. The employees who tend to work stress will feel frustrated, emotional, and uncomfortable at work. , so that it can trigger failure in the organization because it can interfere with one another in carrying out tasks Stress is a condition of tension that creates a physical and psychological imbalance, which affects emotions, thought processes and conditions of an employee. Work stress arises from a variety of things that make employees feel less comfortable.

While conflict is a clash between two parties, who are meeting and crossing the road at an event point, which results in a collision. In the company, many things that trigger conflict occur such as the perception of 
individuals or groups that each group feels different and this disruption causes conflict in ideas or interests, so that these differences obstruct the desires or goals of other individuals or groups

According to Champoux (2017), conflict is a matter of dispute or struggle between two parties, which is marked by showing open hostility and deliberately disturbing the achievement of the objectives of the opposite party." Conflict within the company must be handled properly, because of differences in status and because different values or perceptions can result in the absence of employees who feel under pressure. According to say: Job stress and employee work conflicts can affect employee performance; employee performance is essential in developing a company ( Schein and Peter, 2017).

According to Dessler (2013), stress is often a reason for a decline in a person's performance due to a negative view of stress. Stress is often regarded as a bad thing and disrupt the overall performance of the organization's employees and hinder its development. The dynamic world of work changes rapidly, so stress is vulnerable to anyone, regardless of profession or occupation. The causes of work stress are the intrinsic factors of work, the role of individuals in the organization, relationships outside the organization, organizational structure or work, and individual characteristics.

The higher job demands with faster changes are a general picture and situation faced by individuals in an organization. Likewise, Palcomtech Vocational Training Center Palembang employees interact daily within their organizations, such as dealing with employees who are sometimes vulnerable to work conflicts or outside the organization, such as dealing with other organizations or serving customers, or workloads that have the potential to experience stress at work. If many employees experience eating, stress will have an impact on decreasing work productivity and organizational health.

Based on the description above, the writer is interested in examining the problems in the thesis research title: "The Effect of Work Stress and Work Conflict on Employee Performance in Palcomtech Vocational Training Center Palembang "

\section{LITERATURE REVIEW AND HYPOTHESIS DEVELOPMENT}

\subsection{Understanding Performance}

The term performance is the transfer of language from performance, which according to the Web Dictionary has the meaning of the task, as quoted by as follows 1) is "achievement" used in context or sentences for example about "high-performance car" (2) is a "performance" that is usually in the phrase "folk dance performance" or folk dance performances. 3) is "the performance of tasks," for example, in the sentence in performing his / her duties (Robbins and Judge, 2019).

Stating, the translation performance of "performance," means: 1) Deeds, implementation of work, work performance, implementation of work that is efficient. 2) Achievement of a person regarding the tasks given to him 3) The work of a worker, a management process, or an organization as a whole, where the results of the work can be concrete and measurable (compared with predetermined standards). 4) Performance is as a record of the outcomes that result from a particular activity during a specific period as well. 5) do not violate the law and are morally and ethically appropriate (Noe et al. ,2015).

While stating HR performance is a term that comes from the word job performance or actual performance (actual work performance achieved by someone) Lussier and Hendon (2019). The definition of employee performance raised by Colquitt at al. (2019) a comparison of the results achieved with the role of labor unity (usually per hour)

Performance is the work of someone who is perfecting these activities by the responsibilities and expected results ". Performance is an action and not an event because of the success of doing work. Askanasy and Daus (2012) define Performance as a record of results obtained from certain job functions or activities over a specified period. Gibson et al. (2012). Based on the description of the above performance can be synthesized understanding of performance is the real behavior and achievement or ability of a person in carrying out organizational tasks

\subsection{Performance Criteria}

Performance criteria are the dimensions of evaluating the performance of someone incumbent, a team, and a work unit. Together these dimensions are performance expectations that individuals and teams try to fulfill in order to achieve organizational strategies. There are three basic types of performance criteria viz

a. Criteria based on the nature of focusing on the personal characteristics of an employee. Loyalty, reliability, communication, and leadership skills are qualities that are important during the assessment process. This type of criterion focuses on how a person is, not in one's job.

b. Behavioral criteria are focused on how to work achievement. Such criteria are essential for jobs that require interpersonal relationships. For example, an employee is friendly or pleasant.

c. Criteria based on results, these criteria are increasingly popular with increasingly emphasized productivity and international competitiveness. This criterion focuses on t rather than how something 
was achieved or produced.

\subsection{Performance assessment}

In principle, performance appraisal is a way of measuring the contributions of individuals in the agency made to the organization. The importance of performance appraisal is concerned with determining the level of individual contribution or performance expressed in the completion of the tasks for which it is responsible. Performance appraisal is primarily to find out how productive an employee is and whether he can perform together or more effectively in the future.

\subsection{Definition of Job Stress}

Work stress is a complex, varied, and dynamic process in which the stressor, views about stress itself, brief responses, health impacts, and variables are interrelated. Work stress can be a source or work stressor that causes an individual's reaction in the form of physiological, psychological, and behavioral.

Work stress is said "as an internal state which can be caused by physical demands on the body (disease conditions, exercise, extremes of temperature, and the like) or by environmental and social situations which are potentially harmful, uncontrollable, or exceeding our resources for coping"

Job stress is an internal condition, which can be caused by physical or environmental demands, and potentially damaging and uncontrolled social situations. Rahim (2011) states that stress occurs when the ability of an individual who is unable to work the load. Job stress can be from two sides, namely the positive side and the negative side. Stress that his condition as something negative is distress, whereas stress that has a positive effect is called rustres. Stress is considered positive because of the stress of an employee who can work better to achieve what he wants (Gabrilla, 2018).

According to Yenidar (2011), if an employee views stress from the negative beside it will also have a negative impact. There are five indicators of work stress: (a) Personal behavior is the condition or activity of the employee itself in the organization. (b) Social support is support from within the organization and support from outside the organization. (c) The wrong organization environment. (d) the workload is the state of work that charged employees or the type of work that must be on time, and (e) the situation of home and work is the condition between the situation in the household and the company.

Some critical aspects of work stress, namely (a) stress matters experienced, also involve the organization or company where individuals work. However, the cause is not only in the company, because household problems that carry over to work and work problems that carry over to home can also be a cause of work stress. (b) Resulting in negative impacts on companies and also individuals, and (c)requires cooperation between the two parties to solve the stress problem.

Working conditions, this includes working conditions for quantitative work overload, qualitative work overload, assembling line systems, decision making, hazardous physical conditions, division of work time, and technological progress (technostress).

There are three symptoms of work stress: (a) Physiological symptoms include abdominal pain, increased heart rate, and shortness of breath, increased blood pressure, headaches, and even heart attacks. (b) Psychological symptoms as for psychological as follows: Anxiety, Tension, Boredom Dissatisfaction in working procrastinating, and (c) Mental symptoms are symptoms that are most often encountered and are from the occurrence of work dissatisfaction. Employees sometimes have tried to reduce the symptoms that arise but failed to cause despair that seemed to continue to be studied, which is usually as learned helplessness that can lead to depressive symptoms, and (d) Symptoms of behavior

Included in the behavioral symptoms are: (a) increased dependence on alcohol and cigarette consumption, (b) do sabotage in doing work, (c) Overeating or reducing unnatural eating as withdrawal behavior, (d) Absenteeism increases and work performance decreases, and (e) Restlessness and sleep disorders

The indicators of work stress are: (a) job demands are factors that o someone's work, such as working conditions and physical layout. (b) The role demands, associated with the pressure exerted on someone as a function of a particular role played in an organization. (c) The interpersonal demands are pressures created by other employees. (d) The organizational structure, agency picture that is the unclear organizational structure, lack of clarity regarding the position, role, authority, and responsibility. (e) The organizational leadership gives management style to the organization. Some parties can create an organizational climate that involves tension, fear, and anxiety.

\subsection{Definition of Work Conflict}

Conflicts usually arise in organizations as a result of communication problems, personal relationships, or organizational structures. Conflict starts when one party is displeased by another party about something that the first party considers essential. Conflict in companies takes many forms and patterns, which hinder individual relations with groups. The difference in views between each person has the potential to cause pain, pain, and 
others. Conflict within the company cannot be avoided but can be minimized for corporate purposes so that employees think critically apathy, and productively. Conflicts can affect the positive or negative emotions of every employee who is fundamental about how their attitudes and behavior in the company (Sekaran, 2016).

According to Silvi (2016), conflict is an interactive process both between intra-individuals and social interventions that is in matters such as discrepancies, disagreements, or irregularities (Paulin and Suneson, 2012).

Causes of conflict include (a) Communication: misunderstanding relating to sentences, a language that is difficult to understand, or ambiguous and incomplete information, and inconsistent manager's style. (b) Structure: power struggles between departments with conflicting interests or assessment systems, competition for limited resources. (c) Personal: incompatible goals or personal social values of employees with the behavior portrayed in their positions, and differences in perceptual value.

Typical forms of conflict that occur in a company include (a) hierarchical conflict (hierarchical conflict), i.e., a conflict that occurs at the organizational hierarchy level. For example, a conflict between colleagues and the director. (b) The functional conflict (functional conflict), namely conflicts that occur from various kinds of departmental functions in the organization. For example, conflicts that occur between the production department with the marketing department, general administration, and personnel, (c) staff conflict with the head of the unit (line staff conflict), which is a conflict that occurs between the unit leader and his staff, especially staff related to authority/work authority. Example: Staff employees informally take excessive authority, (d) formal-informal conflict (formal-informal conflict), namely conflicts that occur related to norms that apply informal organizations with formal organizations. Example: Leaders who place the wrong norms of the organization.

Several types of workplace conflicts that commonly occur in a company include (a) conflict within a person. Conflict within a person can arise if there is a case of overload where he is burdened with too much work responsibilities, and can also occur when faced with a point where he must make a decision that involves the best alternative, (b) interpersonal conflict. Personal or interpersonal conflicts can be substantive or emotional, even the leading case of conflict faced by managers in interpersonal relationships as part of managerial itself, (c) intergroup conflict. Intergroup conflict is familiar to any organization, and this conflict makes it difficult to coordinate and integrate activities related to tasks and work, and (d) intra-organic conflict. This conflict is often associated with the competition that arises between private companies. The inter-organization conflict is related to a more significant issue; for example, the dispute between the union and the company. In each case, the process of conflict involves individuals who represent the organization as a whole, not just internal subunits or groups.

\subsection{Previous Research}

There are previous studies about the effect of work stress and work conflict on employee performance, including:

1."The effect of work stress and work conflict on employee performance in the Lampung Post daily newspaper" which concludes that there is a negative and significant influence of work stress on employee performance, positive and significant influence of work conflict on employee performance, as well as positive and significant effects of work stress and conflict work performance of employees. This study concludes that workers tend to experience more work stress than work conflict, which can impact employee performance (Ngah et al. 2010).

2. Titled "the effect of a work conflict and work stress on employee performance at PT. Bank Negara Indonesia (Persero) Tbk Branch Manado ". The conclusion that work conflict and work stress have a significant effect on employee performance. Hypothesis test partially shows that work conflict has a significant effect, and work stress does not have a significant effect on employee performance. PT. BNI Manado Branch pays special attention to every employee who has problems with coworkers about work that causes conflict and work stress so that employee performance can improve (Shakouri, 2014).

3. Titled "The effect of work stress and work motivation on employee performance at PT. Gapura Angkasa Palembang Branch ". Which concluded that work stress and work motivation have a simultaneous and partial effect on employee performance at PT. Gapura Angkasa Palembang Branch. (Thuner et al., 2012)

\subsection{Hypothesis Development}

\section{2..6.1. The simultaneous effect of work stress and work conflict on performance}

Work stress can occur within employees, and it is due to the continuous pressure from superiors and the intimidation of co-workers. Much work will not infrequently cause work stress. Continuous work stress will reduce employee morale. So that productivity and performance decrease. The work enviroeConflicts that occur in the work environment are a source of stress; employees who are angry with each other and mutually will make the environment uncomfortable. Work that should be in teams and together is also the cause of stress because 
each employee only focuses on contributing according to wor,k, which he must do without regard to the work of other employees. If the employees do not support each other in work, the company will not achieve its vision and mission targets. Work stress accompanied by work conflict creates an atmosphere that is not conducive, and performance is not optimal.

Hypothesis 1: Work stress and work conflict simultaneously affect the performance of Palcomtech Vocational Training Center employees

2.6.2. Effect of work stress on performance

Stress levels faced by employees can be relative, and depend on the ability of someone, moderate levels of work stress can improve employee performance; otherwise, if a high-stress level will reduce the spirit of performance and productivity of the company. Employees who are not suitable for their work will result in the work produced will not comply with the specified standards, and added intimidation and pressure from superiors or coworkers will affect the quality of work. The risks faced by each employee in different divisions are different. With these high risks, employee performance will be more careful and hesitant so that the quality of work decreases. High company targets and expectations make employees who are unable to consider it as pressure and not motivated to achieve these targets.

Hypothesis 2: Work stress significantly affects the performance of Palcomtech Vocational Training Center employees

2.6.3. Effect of work conflict on employee performance

Employees who are often angry and emotional will make employees feel uncomfortable. If there is a dispute between fellow employees, it will reduce the productivity of the company when they have to work together in teams to solve and focus their work provided by superiors, and this often happens in the work environment. Hostilities that arise from prolonged bickering will affect the company's vision and mission and targets. Companies will more slowly complete work because their employees are involved in the conflict. Of course, it will affect the existence of the company in the eyes of its business partners. Therefore the company must make this the focus of the problems faced by the company.

Hypothesis 3: Work conflicts significantly affects the performance of Palcomtech Vocational Training Center employees

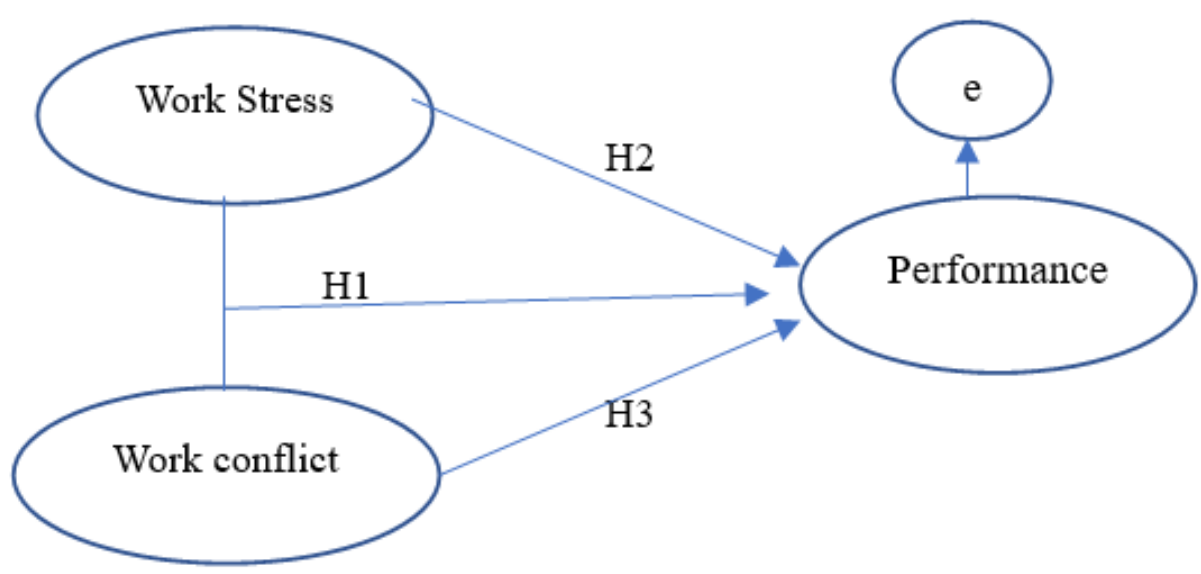

Figure 1. The Research Model

\section{RESEARCH METHODOLOGY}

Alqaryoti et al. (2016) argued that the study is at Palembang PalComTech Vocational Center at Jenderal Sudirman Street, Palembang. While the sample, according to is part of the population that will be the object of research. According to Gonzalez et al. (2014). When the population is less than 100 are taken all up to the research is population research. Based on this theory, the sampling is using all members of the population. In this study, because the population is small (limited), and because the total population in this study is less than 100 people, that is only 30 people, then the entire population is sampled. The method used is a quantitative survey with a descriptive approach. In conjunction with this technique, the survey further states that it is a research technique in which information is using a questionnaire. Kumar, A.A. \& Kalva.U.K (2015)

\subsection{Variables measurement}

Performance

Performance is a work achievement achieved by the work unit in realizing the targets set. Operationally performance is a phenomenon to explain precisely, while the dimensions of performance variables are: (1) 
quantity of work results, (2) quality of work results, and (3) ability to work

Work Stress

Job stress is a complex, varied, and dynamic process in which the stressor, views about stress itself, brief responses, health impacts, and variables are interrelated. Stress occurs when the ability of an individual who is unable to work the load. Operationally performance is a phenomenon to explain precisely, while the dimensions of performance variables are: (1) workload, (2) influence of leadership, (3) employee work time, (4) targets and expectations, and (5) dangerous work.

Work Conflict

Conflict is a clash between two parties who are meeting and crossing the road at an event point, which results in a collision. Conflicts can affect the positive or negative emotions of every employee who are fundamental about how their attitudes and behaviors in the company, such as (1) task conflicts, (2) relationship conflicts, and (3) process conflicts.

\subsection{Data analysis}

Analysis techniques with descriptive and inferential statistics through the requirements test: Normality Test, Homogeneity Test, Linearity Test, Multicollinearity Test, Heteroscedasticity Test, and Autocorrelation. Hypothesis testing with multiple regression models

$$
\begin{aligned}
& \mathrm{Y}=\mathrm{a}+\mathrm{b} 1 \mathrm{X} 1+\mathrm{b} 2 \mathrm{X} 2+\mathrm{e} \\
& \text { Where : } \\
& \mathrm{Y}=\text { Employee Performance Variable } \\
& \mathrm{a}=\text { constant } \\
& \mathrm{b}_{1}, \mathrm{~b}_{2} \text {, = Regression coefficient } \\
& \mathrm{X}_{1}=\text { Work stress } \\
& \mathrm{X}_{2}=\text { Work conflict } \\
& \mathrm{e}=\text { Error of estimates }
\end{aligned}
$$

\section{Hypothesis Testing}

Simultaneous hypothesis testing:

$$
\mathrm{H}_{0} ; \mathrm{b}_{1} \mathrm{~b}_{2}=0, \mathrm{H}_{1} ; \mathrm{b}_{1} \mathrm{~b}_{2} \neq 0 \text {, }
$$

Decision rules: Accept $\mathrm{H}_{0}$, if sig $\mathrm{F} \geq 0.05$, or Reject $\mathrm{H}_{0}$, if sig $\mathrm{F}<0.05$

Simultaneous hypothesis testing:

$$
\mathrm{H}_{0} ; \mathrm{b}_{1} \mathrm{~b}_{2}=0, \mathrm{H}_{1} ; \mathrm{b}_{1} \mathrm{~b}_{2} \neq 0 \text {, }
$$

Decision rules: Accept $\mathrm{H}_{0}$, if $\operatorname{sig} \mathrm{T} \geq 0.05$, or Reject $\mathrm{H}_{0}$, if $\operatorname{sig} \mathrm{T}<0.05$

\section{RESULTS AND DISCUSSION}

\subsection{Descriptive Analysis}

Before the descriptive analysis, it is essential to test the validity and reliability of the instrument. This section describes the results of both independent and dependent variable data consisting of work stress, work conflict, and employee performance. The Cronbach's Alpha test shows 0.984. The reliability test shows that the instrument is valid and reliable.

Work performance

From the instrument test of the work stress of the 12 items, the Cronbach Alpha was 0.912; this shows that work performance is reliable with the critical value of Cronbach $>0.6$.

Work stress

From the instrument test of the work stress of the 14 items, the Cronbach Alpha was 0.982; this shows that work stress was reliable with the critical value of Cronbach $>0.6$.

Work conflict

From the instrument test of the work conflict of the ten items, the Cronbach Alpha was 0.963; this shows that work conflict was reliable with the critical value of Cronbach $>0.6$.

Table 1. Descriptive Data Analysis

\begin{tabular}{|l|c|l|l|c|l|}
\hline & $\mathrm{N}$ & Minimum & Maximum & Mean & Std. Deviation \\
\hline Work stress & 35 & 37,00 & 89,00 & 50.0000 & 8,16016 \\
\hline Work conflict & 35 & 23,00 & 50,00 & 38,1429 & 9,24548 \\
\hline Work performance & 35 & 16.00 & 30,00 & 23,4286 & 4,90059 \\
\hline Valid N (Listwise) & 35 & & & & \\
\hline
\end{tabular}

Source: Processed Data with SPSS 22

The results of the analysis above show that the number of observations $(\mathrm{N})$ is 35 people; work stress has an average value of 50,0 with a standard deviation of 8,16016 . Work conflict has an average of 38.1 , with a standard deviation of 9.2. The dependent variable employee performance has an average of 23.4286 with a 
standard deviation of 4.9

\subsection{Inferential Analysis}

Table 2 shows that partially, work stress and work conflict significantly affect employee performance. These findings based on the $t$ values -5.872 or $p$-value 0.000 for work stress and -.4 .996 or 0.000 for workplace conflict. Table 2. Effects of Job Stress and Work Conflict on Employee Performance Coefficients

\begin{tabular}{|c|c|c|c|c|c|}
\hline \multirow[t]{2}{*}{ Model } & \multicolumn{2}{|c|}{$\begin{array}{c}\text { Unstandadized } \\
\text { Coeficien }\end{array}$} & Standardized Coeficient & \multirow[t]{2}{*}{$\mathrm{t}$} & \multirow[t]{2}{*}{ sig. } \\
\hline & B & $\begin{array}{l}\text { Std. } \\
\text { Error }\end{array}$ & Beta & & \\
\hline $\begin{array}{l}1 \text { (Constant) } \\
\text { Work stress }\end{array}$ & $\begin{array}{r}28,929 \\
-.305\end{array}$ & $\begin{array}{r}4,927 \\
.061\end{array}$ & .508 & $\begin{array}{l}-5.872 \\
-4.996\end{array}$ & $\begin{array}{l}.000 \\
000\end{array}$ \\
\hline Work conflict & -.256 & .054 & .483 & -4.7445 & .000 \\
\hline
\end{tabular}

Dependent on employee performance variables

Source: SPSS 22 processed data source

Table 3 shows that simultaneously, work stress and work conflict significantly affect employee performance - these findings based on the F values 155.555 or p-value 0.000 .

Table 3. F Test

Effect of Job Stress and Work Conflict on Employee Performance

\begin{tabular}{|c|c|c|c|c|c|}
\hline Model & Sum.of Square & Df & Mean Square & F & Sig \\
\hline 1 Regression & 740.414 & 2 & 370.207 & 155.555 & .000 \\
Residual & 76,157 & 32 & 2.380 & & \\
Total & 818.571 & 34 & & & \\
\hline
\end{tabular}

a. Dependent variable: Employee performance

b. Predictor: (Constant): Work conflict, Work Stress

Source: Processed data from SPSS 22

Based on the Sig. T $=0,000$ that work stress has a negative effect on employee performance.

\section{CONCLUSIONS AND RECOMMENDATIONS}

1. Work stress and conflict simultaneously affect the performance of employees. Improving employee performance can be by creating a program to reduce work stress and family conflict together.

2. Job stress has a negative effect on employee performance. The efforts of improving employee performance by creating a work stress reduction program.

3. Work conflicts negatively affect employee performance. The effort to improving employee performance To improve employee performance, it suggested creating a work conflict reduction program.

4. The next researcher can research examining other variables than those suggested to improve employee performance

\section{References}

1. Alqaryouti, O., Alqudah, A., \& Shaalan, K. (2016). Effective Knowledge Management in Projects: Characteristics and Integration. In Information and Knowledge Management (Vol. 6, No. 8, pp. 27-33).

2. Champoux E. Joseph (2017). Organizational Behavior: Integrating Individuals, Groups, and Organizations, Fifth Edition. Routledge.

3. Colquitt A. Jason, Lepine A. Jeffery, and Wesson J. Michael (2019). Organizational Behavior: Improving Performance \& Commitment in the Workplace, the 6th Edition. McGraw-Hill Education.

4. Dessler Gary (2013). Human Resource Management, Fifteenth edition. Pearson

5. Evalina Yusri, (2016) Effect of Work Stress and Work Conflict on Employee Performance in Lampung Post's General Daily Newspaper, Postgraduate Management Program, Faculty of Economics and Business, University of Lampung.

6. Gonzalez, K.V.D. \& Martns, M.F. (2014). Knowledge Management: an Analysis From Organizational Development. Journal of Technology Management \& Innovation 9(1), pp. 131-147.

7. Gabriella Wanur, Janjte Sepang, and Lucky Dutolong (2018) Effects of Work Conflict and Work Stress on Employee Performance at PT. Bank Negara Indonesia (Persero) Tbk Branch. EMBA Journal, Vol. 6 No. January 1, 2018, Pg. 51-60, accessed on September 1, 2018.

8. Gibson L. James, Ivancevich M. John, Donnelly H. James, Konopaske Robert Jr.(2012). Organizations: Behavior, Structure, Processes, Fourteenth Edition. McGraw-Hill. 
9. Haryono, Siswoyo; Nur'aini Hanifah, and Mohd Shamsuri Md Saad (2019). Work-Family Conflict role on the Effects of Workload Towards Medical. Opción, Año 35, Especial No.20 (2019): 1196-1223 ISSN 10121587/ISSNe: 2477-9385

10. Leung, Mei-Yung and Janet, Sham and Yee, Shan Chan (2007), Adjusting Stressors-Job Demand Stress in Preventing Rustout / Bunount in Estimators, Surveying and Built Environment, Vol. 18 (1) .pg. 17-26 ISSN 1816-9554

11. Lussier N. Robert and Hendon R. John (2019). Human Resource Management: Functions, Applications \& Skill Development, 3rd Ed., Sage Publications.

12. Machado Carolina and Davim Paulo J. (2018). Organizational Behaviour and HRM: A Guide to a Specialized MBA Course. Springer

13. Noe A. Raymond, Hollenbec R. John, Gerhart Barry, Wright M. Patrick (2015). Human Resource Management: Gaining a Competitive Advantage, $10^{\text {th }}$ Edition. McGraw-Hill Education

14. Ngah, Rohana, and Ibrahim, Abdul Razak (2010) The effect of knowledge sharing on organizational performance in small and medium enterprises. In: Knowledge Management International Conference 2010 (KMICe2010), 25-27 May 2010, Kuala Terengganu, Malaysia.

15. Pangil, F. \& Nasurddin, A. (2013). Knowledge \& the importance of knowledge sharing in an org. in: Conference on Business Management Research 2013, December 11, 2013, EDC, Universiti Utara Malaysia, Sintok

16. Paulin, D. \& Suneson, K. (2012). Knowledge Transfer, Knowledge Sharing \& Knowledge Barriers - Three Blurry Terms in KM. The Electronic Journal of Knowledge Management 10(1), pp. 81-91.

17. Rahim, Afzalur (2011). Managing Conflict in Organizations, 4th Edition, New Jersey Transaction Publisher.

18. Robbins P. Stephen, Judge A. Timothy (2018). Essentials of Organizational Behavior, Fourteenth Edition. Pearson

19. Schein H. Edgar and Schein, Peter (2017). Organizational Culture and Leadership 5th Edition. Wiley

20. Sekaran Uma and Bougie, Roger (2016). Research Methods for Business. The Seven ${ }^{\text {th }}$ Edition, John Willey \& Sons.

21. Silvia (2016) Effect of Organizational Commitment, Organizational Culture, and Job Satisfaction on Administrative Performance of Employees at SMK N 6 Palembang, Postgraduate Management Program at Tridinanti University, Palembang

22. Shakouri, N. (2014). Qualitative Research: Incredulity toward Metanarrativeness. Journal of Education and Human Development 3(2), pp. 671-680.

23. Turner, J.R., Zimmerman, T. \& Allen, T. (2012). Teams as a Process for Knowledge Management. Journal of Knowledge Management 16(6), pp. 1-31.

24. Yenidar (2011) Effect of Work Stress and Work Motivation on Employee Performance at PT. Gapura Angkasa Palembang Branch, Postgraduate Management Program at Tridinanti University, Palembang. 